\title{
Segregationens båda poler
}

\author{
Recension av Jonas Lindström, Segregation \\ (Liber, Stockholm 2019)
}

\section{MIKAEL STIGENDAL}

Var ska man tala om segregation? Det kom jag att tänka på när jag i juni 2019 lyssnade på ett inslag i Prss Studio Ett om Järvaveckan. Där satt inbjudna och talade om segregation på Spånga idrottsplats i nordvästra Stockholm. Men bidrog de därigenom inte till att förknippa segregation med utsatta områden? Frågan ställdes till Ahmed Abdirahman, grundare och arrangör av Järvaveckan. Han höll inte med utan menade att Järvaveckan har arrangerats precis på gränsen mellan å ena sidan Sveriges till befolkningen största utsatta område och å andra sidan ett mer välbeställt område i Spånga. Det må så vara att Järvaveckan blev ett lyckat möte mellan människor av olika slag men fokus låg på de så kallade utsatta områdena.

Inom segregationsforskningen brukar detta kallas den ena segregationspolen. Enligt den gängse definitionen handlar begreppet "segregation” om hur sociala uppdelningar sammanfaller med rumslig åtskillnad. Det räcker således inte med att till exempel vissa är rika och andra är fattiga. De rika och fattiga måste också bo på olika ställen.

Allt det här har Jonas Lindström full koll på. Han har skrivit en utmärkt bok som kort och gott heter Segregation och ingår i Libers serie Begreppbart. Lindström är särskilt kritisk mot det ensidiga synsätt som massmedia och politiker ofta gör sig skyldiga till. Blicken fästs vid sådant som Järvafältet trots att segregation förutsätter förekomsten av minst två poler. Det är i relationen mellan dessa poler som segregation uppstår. 
Det behöver inte nödvändigtvis vara dåligt, som Lindström skriver, men när den ena polen präglas av exempelvis fattigdom, arbetslöshet och ohälsa så blir det dåligt och då inte bara för den enskilde utan för hela samhället. Hur mycket tänker vi på Äppelviken i Bromma när vi tänker på segregation?, undrar Lindström. Och den tanken ligger nog inte så nära till hands. Vi tänker nog inte heller så mycket på Djursholm, ett annat exempel som Lindström tar upp. Segregation förknippas bara med den ena polen. När det talas om segregation visas vanligtvis höghus upp. Men segregation är ett begrepp som angår oss alla.

Och det gäller inte bara det som kallas boendesegregation, det vill säga där den sociala uppdelningen sammanfaller med att man bor på olika ställen. Den rumsliga åtskillnaden kan också gälla till exempel arbetsplatser eller skolor. Lindström anknyter till den vanliga men också ganska grova uppdelningen i socioekonomisk, etnisk och demografisk segregation. Därutöver talar han om könssegregation, skolsegregation, ålderssegregation och stad och land-segregation.

Det blir dock inte helt tydligt vad han ser som socialt uppdelat respektive rumsligt åtskilt i dessa senare typer av segregation. Ålderssegregation sägs till exempel syfta "på hur ålder kan spela roll när det gäller livsvillkor". Det gör det säkert men det framgår inte vad det har med segregation att göra eftersom ingen rumslig åtskillnad klargörs. En liknande oklarhet gäller det han kallar könssegregation. Det sägs inledningsvis (s. 23) handla om hur skillnader mellan män och kvinnor vad gäller löneoch arbetsvillkor sammanfaller med att de arbetar på olika håll, det vill säga en rumslig åtskillnad. Men när han senare i boken återkommer till könssegregationen handlar det mer ensidigt om normer. Det får mig att sakna de "teoretiska överväganden kring vad som är en rimlig geografisk nivå för att undersöka segregation”, som han betonar vikten av (s. 8I), "på samma sätt som när samhällsforskare definierar vem som är 'medelklass' eller 'svensk' ..." Det är dock ingen allvarlig kritik men förtjänar ändå att nämnas eftersom segregationsbegreppets styrka, som jag ser det, ligger just i kombinationen av det sociala och det rumsliga. Det är därför viktigt att hålla fast vid.

En stor förtjänst med Lindströms bok är att han skiljer mellan segregation som fenomen och som begrepp. Det banar väg för poänger om 
"hur vi gör skillnader utifrån föreställningar som allt som ofta inte stämmer överens med faktiska förhållanden” (s. 43). Det banar också väg för intressanta historieskrivningar. Den första gäller Chicago där begreppet "segregation" lanserades. Lindström skriver om den historiska process som ledde till framväxten av segregation som fenomen. Det uppmärksammades och begreppsliggjordes av Chicagoskolan. Frågor om segregationen som fenomen respektive begrepp behandlas var för sig men också sammankopplade på ett övertygande sätt.

Lindström har en intressant reflektion om hur Chicago men också Los Angeles har kommit att förknippas med segregation. En hel del av forskningen har fokuserat på dessa två städer och då har det inte bara gällt segregationen som fenomen. I båda städerna har det även funnits starka och inflytelserika forskningsmiljöer. Chicago och Los Angeles är dessutom kända genom populärkulturen och referenserna till den är en annan av bokens förtjänster. Lindström har koll på både den ene och den andre, till exempel Blade Runner och Fresh Prince i Bel Air.

När till och med Sonya Hedenbratt citeras blir man imponerad, även om hon aldrig ingick bland mina favoriter och man undrar varför inte en enda skåning finns med bland de populärkulturella referenserna. Men då är vi framme vid ytterligare en historieskrivning, den om hur såväl fenomen som begrepp har vuxit fram i Sverige. Även denna historieskrivning läser jag med stor behållning och där kopplar Lindström även segregationsbegreppet till integration.

Innan historieskrivningen om Sverige fördjupar sig dock Lindström i orsakerna till segregation. Han är nämligen angelägen om att inte bara uppfatta segregation som ett tillstånd utan också som en process, det vill säga som skillnader som görs. Segregationens orsaker och följder ska inte blandas ihop, skriver han. Men vilka är då segregationens orsaker? Det belyser han förtjänstfullt i sin historieskrivning om Chicago men när han ska begreppsliggöra dessa orsaker blir jag lite undrande. Han är inte riktigt trogen sin distinktion mellan fenomen och begrepp.

I min tankevärld kan fenomenet bestå av det vi gör, vare sig det är avsiktligt eller ej, vare sig vi tänker på det eller ej. Med begrepp kan vi göra fenomenet meningsfullt. Definitionen av begreppet innebär att vi gör det till en del i ett meningssammanhang där då även andra begrepp 
ingår. Tack vare detta meningssammanhang kan vi orientera oss. Begreppet och det meningssammanhang som det ingår i hjälper oss att gå vidare i en komplext fenomenfylld verklighet.

Lindström uppmanar oss att fästa uppmärksamheten på att segregationens skillnader görs. Utifrån ovanstående resonemang ser jag det dock som att i huvudsak två skillnader görs. I kapitlet om Chicago skriver han om båda dessa processer. Han skriver om förändringarna av arbetsprocessen på Henry Fords bilfabrik, hur bilen förverkligade den amerikanska förortsdrömmen, uppfinnandet av skyskrapan, migrationen av fattiga afroamerikaner från söderns landsbygd, första världskrigets betydelse och hur allt detta orsakade fenomenet segregation. Men han skriver även om hur det gick till när Chicagoskolan försökte förstå denna utveckling genom att göra segregation till ett begrepp och del i ett meningssammanhang, i det här fallet en teori.

I kapitlet om orsakerna till segregationen handlar det dock mest om den skillnad som gäller meningssammanhangen; om hur till exempel polariseringar och motsatser görs i vi och dom, mellan könen och genom associationer. Inriktningen på meningssammanhangen blir särskilt tydlig i avsnittet om diskursiv makt. Jag har ingenting emot allt detta, tvärtom. Det är viktigt för förståelsen av segregation. Min kritik gäller avsaknaden av den andra sidan, den sida som befolkningen vid den andra segregationspolen bidrar till att göra, beroende på till exempel vad de förvärvsarbetar med, vad de har betalt för sitt boende, den skuld de har satt sig i, hur mycket ränte- och RUT-bidrag de får av staten, var deras barn går i skolan, om de har privat sjukförsäkring och så vidare. Det är också viktigt för att man ska förstå varför de skillnader som kallas segregation görs.

Förresten deltog även Jonas Lindström i debatten på Spånga IP. Han argumenterade förtjänstfullt för behovet av att lyfta blicken, synliggöra även segregationens andra pol, prata om orsakerna och spåra dessa till andra platser i samhället. Jag undrar därför hur han tänkte om att sitta där och delta i ett sammanhang med fokus på den ena segregationspolen. Bidrog han då inte till att göra segregation? Jag var dock inte bättre själv när jag innan valet 2018 deltog i en liknande tillställning i Malmö som hette Malmedalen. Lindström satt i alla fall på gränsen mel- 
STIGENDAL | SEGREGATIONENS BÅDA POLER

lan segregationspolerna. Malmedalen arrangerades mitt inne i ett av de 23 områden i Sverige som polisen betraktar som särskilt utsatta: Rosengård söder om Amiralsgatan. Det är inte så lätt att tala om segregation. $\mathrm{Nu}$ finns det dock hjälp att få av Jonas Lindströms bok och den kan jag varmt rekommendera. 


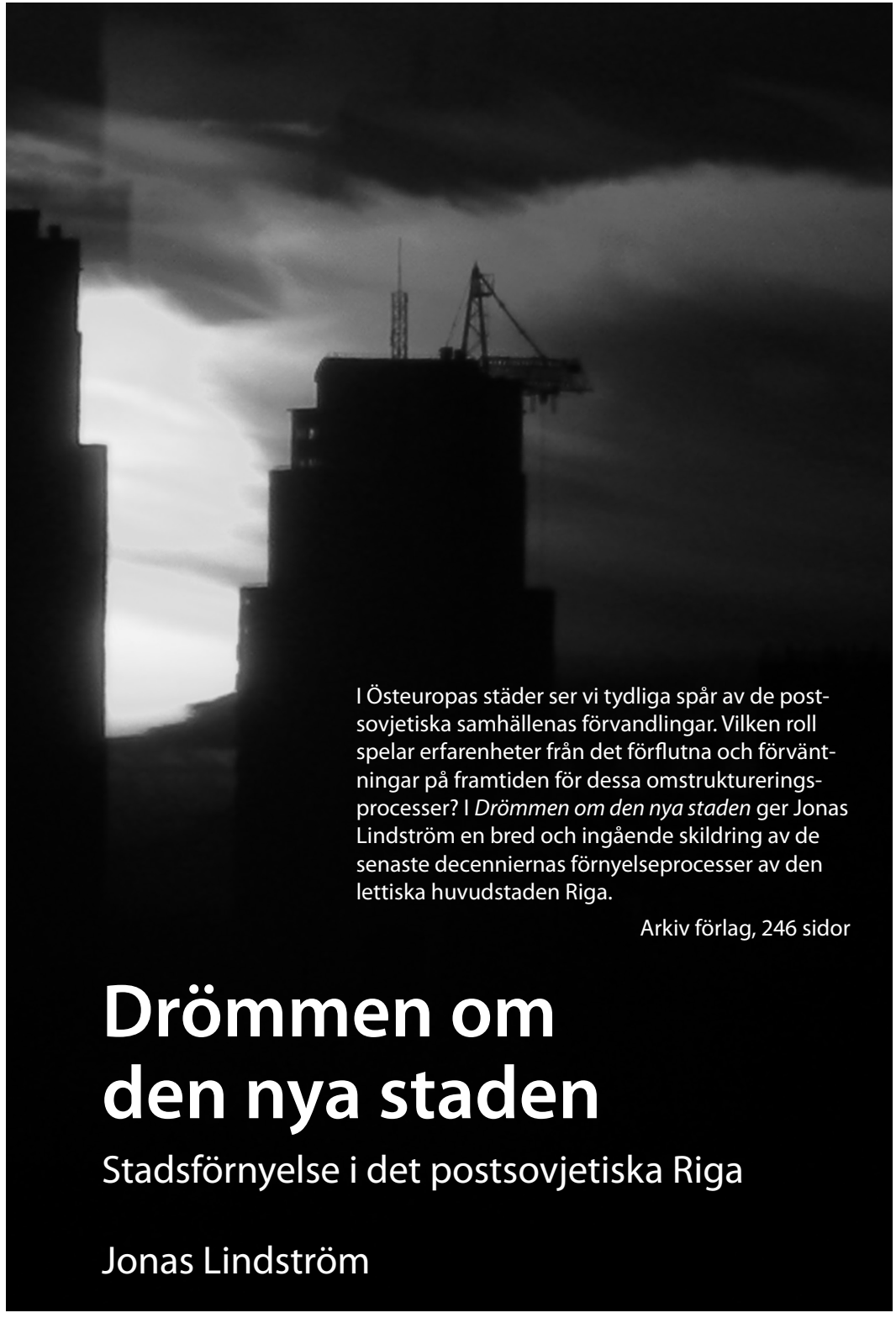

»Läs mer om boken på www.arkiv.nu« 